\title{
Effect of Grafting on Growth and Incidence of Phytophthora Blight and Bacterial Wilt of Pepper (Capsicum annuum L.)
}

\author{
Yoonah Jang ${ }^{1}$, Eunyoung Yang ${ }^{1}$, Myeongcheoul $\mathrm{Cho}^{1}$, Yeongcheol $\mathrm{Um}^{1}$, Kwandal $\mathrm{Ko}^{1}$, and Changhoo Chun ${ }^{2,3^{*}}$ \\ ${ }^{1}$ National Institute of Horticultural \& Herbal Science, Rural Development Administration, Suwon 440-706, Korea \\ ${ }^{2}$ Department of Plant Science, College of Agriculture and Life Sciences, Seoul National University, Seoul 151-921, Korea \\ ${ }^{3}$ Research Institute for Agriculture and Life Sciences, Seoul National University, Seoul 151-921, Korea \\ *Corresponding author: changhoo@snu.ac.kr
}

Received September 14, 2011 / Revised December 9, 2011 / Accepted December 12, 2011

(C) Korean Society for Horticultural Science and Springer 2012

\begin{abstract}
This study was conducted to investigate the effect of grafting using commercial rootstocks and breeding lines on growth and resistance to both Phytophthora blight (Phytophthora capsici) and bacterial wilt (Ralstonia solanacearum), and to evaluate the breeding lines as candidates rootstocks for grafted peppers. Capsicum annuum 'Nokkwang' (scion) was grafted onto five commercial rootstocks ('Kataguruma', 'Konesianhot', 'Koregon PR-380', 'PR-power', and 'Tantan') and nine breeding lines ('PR 901', 'PR 919', 'PR 920', 'PR 921', 'PR 922', 'PR 927', 'PR 928', 'PR 929', and 'PR 930'). Graft-take percentage was over $80 \%$ in all the grafted seedlings except those grafted onto 'PR 901' (75\%). The number of leaves, stem diameter, leaf area, and dry weight of shoot of grafted seedlings were greater than those of non-grafted seedlings. Mineral contents in the shoots of grafted seedlings were significantly different, depending on rootstock genotypes. Marketable yield ranged from 1.35 to $1.96 \mathrm{~kg}$ per plant depending on rootstock genotypes, and was highest in peppers grafted onto 'PR 901' $(1.95 \mathrm{~kg})$ and non-grafted peppers (1.96 kg), and lowest in those grafted onto 'PR 928' (1.35 kg). Gross yield was highest in peppers grafted onto 'Konesianhot' (2.64 kg). Among nine breeding lines, three rootstocks ('PR 920', 'PR 921', and 'PR 922') were selected as candidate rootstocks for the grafted pepper based on graft-take, growth, yield, fruit quality, and resistance to diseases. Three major pepper cultivars ('Nokkwang', 'Saengsaeng Matkkwari', and 'Shinhong') were grafted onto those three breeding lines and 'Tantan' (control). Peppers grafted onto breeding lines of 'PR 920', 'PR 921', and 'PR 922' showed greater resistance to both Phytophthora blight and bacterial wilt without the decrease in yield and fruit quality. Accordingly, they were considered to be used as rootstocks resistant to both Phytophthora blight and bacterial wilt for pepper production.
\end{abstract}

Additional key words: rootstock, soilborne disease, Phytophthora capsici, Ralstonia solanacearum

\section{Introduction}

Pepper (Casicum annuum L., Solanaceae) is the most important and widely cultivated vegetable in Korea. In 2009 , the cultivation area of pepper, including green pepper, was 50,521 ha and its yield was $350,436 \mathrm{t}$ while the value of pepper production reached 1,212 billion won (MIFAFF, 2010). Red and green peppers have been cultivated intensively around Gyeonbuk and Gyeongnam region, respectively. Under continuous cropping practices of peppers, salt accumulation and soilborne diseases consequently reduce the yield and quality of the produce. Two soilborne diseases, Phytophthora blight and bacterial wilt caused by Phtytophthora capsici and Ralstonia solanacearum, respectively, are the most devastating diseases in pepper production (Kim and Kim, 2002; Myung et al., 2006).
Numerous attempts have been made to improve the disease resistance of pepper crops. One of the major goals in pepper breeding is the development of a cultivar completely resistant to soilborne diseases. However, that is very difficult to achieve and requires much time and effort. For the alleviation of soil born diseases, cultural practices such as crop rotation and sanitation are recommended, but pesticide is generally applied to control the diseases (Kim et al., 2010; Semi et al., 2010; Tran and Kim, 2010; Yeon et al., 2008).

Grafting is an environment-friendly alternative method for disease control (Oka et al., 2004; Rivard and Louws, 2008). Grafting scions onto resistant rootstocks makes it possible to control soilborne diseases and increase yield of the susceptible cultivar (Lee and Oda, 2003). Recently, the cultivated area of grafted Solanaceae and Cucubitaceae has increased tremendously (Lee et al., 2010). At present, 
grafting is mainly used in order to reduce infections by soilborne pathogens and to enhance the tolerance against abiotic stresses (King et al., 2008; Louws et al., 2010; Rivero et al., 2003).

In order to prevent soilborne diseases in continuous cropping, peppers are generally grafted onto the rootstocks that are of the same species as scions $(C$. annuиm L.) that have resistance to Phytophthora blight (King et al., 2010). It was reported that grafting of peppers also improved tolerance to high salt conditions (Chung and Choi, 2002) and low temperature (Jang et al., 2008). However, few commercial rootstocks resistant to Phytophthora blight are resistant to the bacterial wilt. Peppers grafted onto rootstocks resistant to Phytophthora blight are reported to be damaged by bacterial wilt in the late stage of cultivation and need additional efforts in order to control bacterial wilt. Accordingly, there is a need to develop pepper rootstocks resistant to both Phytophthora blight and bacterial wilt.

Rootstock should not only have resistance to diseases but also have good compatibility with scion and be able to maintain yields and fruit quality of the scion variety. This study was conducted to investigate whether commercially available rootstocks and new breeding lines affect growth and resistance to both Phytophthora blight and bacterial wilt of grafted plants, and to evaluate breeding lines as a new rootstock.

\section{Materials and Methods}

\section{The Growth and Incidence of Phytophthora Blight of the Grafted Peppers as Influenced by Different Rootstocks}

Plant Materials and Growing Seedlings

'Nokkwang' (Seminis Inc.) that is susceptible to
Phytophthora blight (Kim et al., 2010) and bacterial wilt (NIHHS, 2009) was used as a scion. The commercial rootstocks and breeding lines resistant to Phytophthora blight and bacterial wilt were evaluated as rootstocks. The genotypes of rootstocks are listed in Table 1. Seeds of scion were sown one week after sowing seeds of rootstocks in order to obtain seedlings of similar diameter with rootstocks. Seeds of scion and rootstock were sown into the 105-cell trays (W $280 \mathrm{~mm} \times \mathrm{L} 540 \mathrm{~mm} \times \mathrm{H} 48 \mathrm{~mm}$, Bumnong Co., Ltd., Jeongeup, Korea) and 72-cell plug trays (W $280 \mathrm{~mm} \times$ L $540 \mathrm{~mm} \times \mathrm{H} 45 \mathrm{~mm}$, Bumnong Co., Ltd., Jeongeup, Korea), respectively, then filled with a commercial growing substrate (BM 2, Berger Group Ltd., Quebec, Canada). Plants were watered daily. A nutrient solution (electric conductivity $1.5 \mathrm{dS} \cdot \mathrm{m}^{-1}$ with 'Hanbang' for seedling, N-P$\mathrm{K}-\mathrm{Ca}-\mathrm{Mg}=8.0-2.4-2.4-4.8-1.6 \mathrm{me} \cdot \mathrm{L}^{-1}$, Coseal Co., Ltd., Gunsan, Korea) was applied and the application frequency was determined depending on growth stage (RDA, 2008b).

\section{Grafting, Healing, and Acclimatization}

Scions (5-6 leaf stage) were grafted onto rootstocks at 36 days after sowing. The epicotyls of scion and rootstock were cut below $1 \mathrm{~cm}$ from first true leaf using a razor blade. After placing the scion on the rootstock, the grafted position was fixed with ordinary grafting clip by slice grafting method. After grafting, plants were healed and acclimatized in the tunnel covered with double-layered plastic film and shade cloth in the greenhouse for one week (Lee et al., 2010). In order to prevent the grafted plants from wilting due to the excessive transpiration and to promote healing, the tunnel was closed for the first three or four days of healing and acclimatization period. For the next three or four days, the opening and closing of the tunnel were done based on the condition of grafted plants and weather. This is for the acclimatization of grafted plants to environmental condition

Table 1. Pepper accessions used as rootstocks in experiments.

\begin{tabular}{lll}
\hline \hline Accession/cultivar & Description & Source \\
\hline Kataguruma & Commercial variety & Sakada Korea Seed Co., Ltd., Korea \\
Konesianhot & Commercial variety & Seminis Inc., Korea \\
Koregon PR-380 & Commercial variety & Koregon Seed Co., Ltd., Korea \\
PR-power & Commercial variety & Nongwoo Bio Co., Ltd., Korea \\
Tantan & Commercial variety & Nongwoo Bio Co., Ltd., Korea \\
PR901 & Breeding line & NIHHS \\
PR919 & Breeding line & NIHHS \\
PR920 & Breeding line & NIHHS \\
PR921 & Breeding line & NIHHS \\
PR922 & Breeding line & NIHHS \\
PR927 & Breeding line & NIHHS \\
PR928 & Breeding line & NIHHS \\
PR929 & Breeding line & NIHHS \\
PR930 & Breeding line & NIHHS \\
\hline
\end{tabular}

${ }^{z}$ National Institute of Horticultural \& Herbal Science, Korea. 
outside the tunnel (RDA, 2008b). Non-grafted and auto-grafted (scion and rootstock were of the same species) 'Nokkwang' seedlings served as controls. After the end of healing and acclimatization, grafted seedlings were grown on the bench in a glasshouse. Before transplanting, the graft-take and the growth parameters of sampled grafted transplants $(n=9)$ were measured. Dry weight was determined after drying at $80^{\circ} \mathrm{C}$. For the determination of mineral contents in shoot, dried shoots $(n=3)$ were grounded and digested in mixed solution of $\mathrm{HNO}_{3}$ and $\mathrm{HClO}_{4}$ (3:1). Total nitrogen and phosphorus content were determined according to the Kjeldahl method and vanadate method, using nitrogen anlayzer (Kjeltec 2300, Foss, Hilleroed, Denmark) and UV-visible spectrophotometer (Shimadzu UV-3150, Shimadzu Co., Kyoto, Japan), respectively. Potassium, calcium, and magnesium content were determined according to an atomatic absorption spectrophotometric method using atomic absorption spectrophotometer (Shimadzu AA-6800, Shimadzu Co., Kyoto, Japan).

\section{Cultivation of Grafted Peppers in a Greenhouse}

The grafted and non-grafted seedlings were transplanted in a greenhouse (W $8 \mathrm{~m} \times \mathrm{L} 3 \mathrm{~m}$ ) covered with polyethylene film, 46 days after grafting (April). After soil test, pre-plant broadcast N-P-manure were applied at a rate of 72-61$20,000 \mathrm{~kg} \cdot \mathrm{ha}^{-1}$ to soil. Three rows were made and each row was mulched with black plastic film prior to planting. Irrigation and additional fertilizer application (fertigation) was carried out using standard procedures for pepper cultivation (RDA, 2008a). Additional fertilizer ('Hanbang' for green pepper cultivation, N-P-K-Ca-Mg $=10.8-3-7-4-2$ $\mathrm{me} \cdot \mathrm{L}^{-1}$, Gunsan, Korea) was applied depending on the growth conditions through a drip irrigation system. The experiment was arranged in a randomized complete block design with three replicates. Each replicate consisted of five plants. Peppers were cultivated for about five months (AprilAugust) and green fruits were harvested weekly from 69 days after transplanting. All the fruits from each plant were harvested, counted and weighed. Fruits $(n=30)$ were selected for the characterization at 76 days after transplanting. Each fruit $(n=15)$ was longitudinally sliced into two and the flesh thickness was measured at the center of the fruit with a caliper gauge. Textural property of the fruit was measured using a texture analyzer (EZ Test-100N, Shimadzu Co., Kyoto, Japan) equipped with a $5 \mathrm{~mm}$ diameter plunger. Compression force into the flesh at $7 \mathrm{~mm}$ depth was monitored at $2 \mathrm{~mm} \cdot \mathrm{s}^{-1}$ speed.

\section{Inoculation of Pathogen}

The Phytophthora blight pathogen, $P$. capsici were obtained from National Academy of Agricultural Science, Rural
Development Administrations. 'Nokkwang' was grafted onto five commercial varieties and four selected breeding lines ('PR 919', 'PR 920', 'PR 921', and 'PR 922') based on their resistance to Phytophthora blight, bacterial wilt, bacterial spot, anthracnose, and virus in the field were used as rootstocks (NIHHS, 2009). Non-grafted and auto-grafted 'Nokkwang' seedlings were used as control. Sixty two-dayold seedlings (31 days after grafting) grafted onto different rootstocks were inoculated by dipping method with $10^{5}$ zoospores $\cdot \mathrm{mL}^{-1}$ suspension. The grafted seedlings inoculated with $P$. capsici were transplanted in the plant pot filled with commercial growing substrate. The experiment was arranged in a randomized block design with three replicates. Each experimental unit consisted of three plants. The survival rate was examined 23 days after inoculation.

\section{The Growth and Incidence of Phytophthora Blight and Bacterial Wilt of the Grafted Peppers as Influenced by Different Rootstocks}

\section{Plant Materials and Cultivation of Grafted Peppers}

Among nine breeding lines, three rootstocks ('PR 920', 'PR 921', and 'PR 922') were selected based on their resistance to pathogen such as $P$. capsici. 'Nokkwang', 'Saengsaeng Matkkwari' (Nongwoo Bio Co., Ltd.), and 'Shinhong' (Nongwoo Bio Co., Ltd.) were used as scions. 'Nokkwang', 'Saengsaeng Matkkwari', and 'Shinhong' seedlings and seedlings grafted onto 'Tantan' served as controls. Grafting was done 32 days after sowing the seeds of scions.

The grafted and non-grafted pepper seedlings were transplanted in a greenhouse $\left(244 \mathrm{~m}^{2}\right)$ covered with polyethylene film at 32 days after grafting (March). After soil test, pre-plant broadcast manure and rice straw were applied at a dose of 20,000 and $5,000 \mathrm{~kg} \cdot \mathrm{ha}^{-1}$ to soil. Green fruits were harvested from May for about six months.

Growing scions and rootstocks, grafting, managing of grafted peppers, sampling, and examination were achieved using the same procedure as the above experiment.

\section{Inoculation of Pathogen}

The Phytophthora blight pathogen, P. capsici and bacterial wilt pathogen, $R$. solanacearum were used. Bacterial wilt pathogen was obtained from Kyungpook National University. Sixty three-day-old seedlings ( 26 days after grafting) planted in a plug tray were used. Six non-grafted seedlings and 15 grafted seedlings grafted onto each rootstock were inoculated by dipping method with $10^{5}$ zoospores $\cdot \mathrm{mL}^{-1}$ of Phytophthora blight pathogens and $10^{8} \mathrm{cfu} \cdot \mathrm{mL}^{-1}$ suspension of bacterial wilt pathogen, respectively (Yang et al., 2010). Disease evaluations were done at 12-34 days after inoculation. 


\section{Statistical Analysis}

The data were subjected to analysis of variance (ANOVA). Statistical computations were carried out using the SigmaPlot version 11 (Systat Software Inc., San Jose, CA, USA) and SAS version 9.1 (SAS Institute Inc., Cary, NC, USA) software.

\section{Results}

\section{The Growth and Incidence of Phytophthora Blight of the Grafted Peppers as Influenced by Different Rootstocks}

Graft-take, Growth, and Mineral Content of Grafted Seedlings

Commercial varieties exhibited high percent germination ( $\geq 96 \%$ ). Among breeding lines, 'PR 901' (64\%) and 'PR 930' (72\%) had low percent germination, followed by 'PR 921 ' (82\%) (Table 2). The other breeding lines showed similar percent germination with commercial varieties. Graft-take was over $80 \%$ in all grafted seedlings except those grafted onto 'PR 901' (72\%). At 30 days after grafting, 'Konesianhot' had the highest percentage of graft-take (94\%).

Growth and mineral content of the pepper seedlings were influenced by grafting (Tables 3 and 4). The number of leaves, stem diameter, leaf area, and dry weight of shoot of grafted seedlings were greater than those of non-grafted seedlings. They varied among different rootstocks. The dry weight was highest in the seedlings grafted onto 'PR 921' followed by 'PR 928' and 'PR 919'. Mineral contents in the shoot of grafted seedlings were significantly different, depending on rootstock genotypes. With respect to total $\mathrm{N}$, pepper seedlings grafted onto 'PR 929' (4.20\%), 'PR 901' (3.98\%), and 'Kataguruma' (3.91\%) presented values exceeding those of control plants (non-graft 3.52\% and auto-graft $3.47 \%$ ). The calcium content in seedling grafted onto 'PR 922 ' $(6.82 \%)$ was 1.9 times higher that of non-grafted seedlings (3.57\%). In contrast, phosphorus content in grafted seedlings was lower than that of non-grafted seedlings.

\section{Yield and Fruit Quality of Grafted Peppers}

Marketable yield ranged from 1.35 to $1.96 \mathrm{~kg}$ per plant depending on rootstock genotypes. The yield of peppers grafted onto 'PR 901' (1.95 kg) and non-grafted peppers $(1.96 \mathrm{~kg})$ were higher than those grafted onto 'PR 928' $(1.35 \mathrm{~kg})$. Gross yield was highest in peppers grafted onto 'Konesianhot' (2.64 kg) (Table 5). Differences among treatments were found for fruit length, weight, flesh thickness, and textural property (Table 6). Fruit length in grafted peppers (average of $12.4 \mathrm{~cm}$ ) was longer than that of non-grafted peppers (average of $12.0 \mathrm{~cm}$ ). Fruits from peppers grafted onto 'PR 901' $(12.9 \mathrm{~cm})$ and 'Konesianhot' $(12.7 \mathrm{~cm})$ were significantly more elongated than those from non-grafted peppers. Fresh weight of fruits from peppers grafted onto 'Konesianhot' was also significantly greater than those from non-grafted peppers. With respect to textural property, the value of strength ranged from 529 to $623 \mathrm{kN}$. $\mathrm{m}^{-2}$, and was highest in fruits grafted onto 'PR 919', and lowest in those grafted onto 'PR 928'. The value of hardness ranged from 5,135 to $6,397 \mathrm{kN} \cdot \mathrm{m}^{-2}$, and was highest in

Table 2. Germination of rootstocks and graft-take of peppers grafted onto these rootstocks when using 'Nokkwang' as scion.

\begin{tabular}{lccc}
\hline \hline \multirow{2}{*}{ Rootstock } & \multirow{2}{*}{ Germination $(\%)$} & \multicolumn{2}{c}{ Graft-take (\%) } \\
\cline { 3 - 4 } Nokkwang (Auto-graft) & $100 \mathrm{a}^{\mathrm{z}}$ & 12 days after grafting & 30 days after grafting \\
Kataguruma & $97 \mathrm{a}$ & $99 \mathrm{ab}$ & $85 \mathrm{ab}$ \\
Konesianhot & $100 \mathrm{a}$ & $85 \mathrm{~cd}$ & $81 \mathrm{ab}$ \\
Koregon PR-380 & $96 \mathrm{a}$ & $94 \mathrm{a}-\mathrm{d}$ & $94 \mathrm{a}$ \\
PR-power & $100 \mathrm{a}$ & $93 \mathrm{a}-\mathrm{d}$ & $93 \mathrm{a}$ \\
Tantan & $99 \mathrm{a}$ & $97 \mathrm{ab}$ & $91 \mathrm{a}$ \\
PR901 & $64 \mathrm{c}$ & $91 \mathrm{a}-\mathrm{d}$ & $90 \mathrm{a}$ \\
PR919 & $99 \mathrm{a}$ & $85 \mathrm{~cd}$ & $72 \mathrm{~b}$ \\
PR920 & $93 \mathrm{a}$ & $97 \mathrm{a}-\mathrm{c}$ & $83 \mathrm{ab}$ \\
PR921 & $82 \mathrm{ab}$ & $87 \mathrm{~b}-\mathrm{d}$ & $87 \mathrm{ab}$ \\
PR922 & $93 \mathrm{a}$ & $98 \mathrm{ab}$ & $80 \mathrm{ab}$ \\
PR927 & $89 \mathrm{a}$ & $85 \mathrm{~cd}$ & $85 \mathrm{ab}$ \\
PR928 & $99 \mathrm{a}$ & $84 \mathrm{~cd}$ & $83 \mathrm{ab}$ \\
PR929 & $97 \mathrm{a}$ & $100 \mathrm{a}$ & $87 \mathrm{ab}$ \\
PR930 & $72 \mathrm{bc}$ & $100 \mathrm{a}$ & $89 \mathrm{ab}$ \\
\hline
\end{tabular}

${ }^{\mathrm{z}}$ Means separation within columns by Duncan's multiple range test $(P \leq 0.05)$. 
Table 3. Growth of grafted pepper seedlings ('Nokkwang') as influenced by grafting and rootstocks.

\begin{tabular}{|c|c|c|c|c|c|c|}
\hline \multirow{2}{*}{ Rootstock } & \multirow{2}{*}{$\begin{array}{l}\text { Shoot length } \\
(\mathrm{cm})\end{array}$} & \multirow{2}{*}{$\begin{array}{l}\text { Number of } \\
\text { leaves }\end{array}$} & \multirow{2}{*}{$\begin{array}{l}\text { Stem diameter of scion } \\
(\mathrm{mm})\end{array}$} & \multirow{2}{*}{$\begin{array}{l}\text { Leaf area } \\
\qquad\left(\mathrm{cm}^{2}\right)\end{array}$} & \multicolumn{2}{|c|}{ Dry weight (mg) } \\
\hline & & & & & Root & Shoot \\
\hline Non-graft & $34 a^{y}$ & $12.8 \mathrm{e}$ & $2.96 \mathrm{~d}$ & $122 \mathrm{c}$ & $94 b-d$ & $609 f$ \\
\hline Auto-graft & $32 \mathrm{bc}$ & $14.6 b-d$ & 3.87a-c & $143 a b$ & $92 b-d$ & 776a-e \\
\hline Kataguruma & $29 e f$ & $14.0 \mathrm{~b}-\mathrm{e}$ & $3.62 a-c$ & $153 a$ & $83 c d$ & $698 c-f$ \\
\hline Konesianhot & $29 \mathrm{ef}$ & 13.7de & $3.58 \mathrm{a}-\mathrm{c}$ & $127 \mathrm{bc}$ & $78 \mathrm{~cd}$ & $658 b-d$ \\
\hline Koregon PR-380 & 30de & $14.7 b-d$ & $3.62 a-c$ & $141 a-c$ & $91 b-d$ & $684 c-f$ \\
\hline PR-power & $33 a b$ & $14.3 b-e$ & 3.61a-c & $152 a$ & $113 a b$ & 767a-e \\
\hline Tantan & $30 c-e$ & $15.7 a b$ & $3.66 a-c$ & $152 a$ & $100 \mathrm{bc}$ & $724 b-f$ \\
\hline PR901 & $25 \mathrm{~h}$ & $16.4 a$ & $4.00 a-c$ & $154 a$ & $107 a b$ & $799 a-d$ \\
\hline PR919 & $31 \mathrm{~cd}$ & $14.7 a-c$ & 3.85a-c & $137 a-c$ & $86 b-d$ & $847 a b$ \\
\hline PR920 & $27 \mathrm{~h}$ & $13.8 c-e$ & $3.46 c$ & $138 a-c$ & $89 b-d$ & $618 f$ \\
\hline PR921 & $30 d-f$ & $14.2 b-e$ & $3.86 a-c$ & $152 a$ & $132 a$ & $869 a$ \\
\hline PR922 & $28 f g$ & $15.4 a-c$ & 4.03ab & $152 a$ & $100 \mathrm{bc}$ & $706 b-f$ \\
\hline PR927 & $31 \mathrm{~g}$ & $15.7 a b$ & $3.48 \mathrm{bc}$ & $155 a$ & $98 \mathrm{bc}$ & 747a-f \\
\hline PR928 & $34 a$ & $15.4 a-c$ & $4.12 a$ & $148 a$ & $106 \mathrm{bc}$ & $827 a-c$ \\
\hline PR929 & $33 a$ & $15.2 a-d$ & 3.83a-c & $141 a-c$ & $93 b-d$ & $810 a-c$ \\
\hline PR930 & $28 f g$ & $13.8 \mathrm{c}-\mathrm{e}$ & 3.86a-c & $153 a$ & $67 d$ & 644 ef \\
\hline
\end{tabular}

${ }^{z}$ Measurement at $1 \mathrm{~cm}$ above the graft union.

${ }^{\mathrm{y}}$ Means separation within columns by Duncan's multiple range test $(P \leq 0.05)$.

Table 4. Mineral content (\% D.W.) of grafted pepper seedlings ('Nokkwang') as influenced by grafting and rootstocks.

\begin{tabular}{llllll}
\hline \hline Rootstock & $\mathrm{T}-\mathrm{N}$ & $\mathrm{P}_{2} \mathrm{O}_{5}$ & $\mathrm{~K}$ & $\mathrm{Ca}$ & $\mathrm{Mg}$ \\
\hline Non-graft & $3.52 \mathrm{~d}-\mathrm{f}^{2}$ & $1.51 \mathrm{a}$ & $9.27 \mathrm{a}-\mathrm{c}$ & $3.57 \mathrm{~b}$ & $1.89 \mathrm{~d}-\mathrm{g}$ \\
Auto-graft & $3.47 \mathrm{ef}$ & $1.39 \mathrm{ab}$ & $7.68 \mathrm{c}$ & $3.77 \mathrm{~b}$ & $2.02 \mathrm{~b}-\mathrm{f}$ \\
Kataguruma & $3.91 \mathrm{a}-\mathrm{c}$ & $1.33 \mathrm{bc}$ & $8.83 \mathrm{a}-\mathrm{c}$ & $4.05 \mathrm{~b}$ & $2.01 \mathrm{~b}-\mathrm{g}$ \\
Konesianhot & $3.51 \mathrm{~d}-\mathrm{f}$ & $1.03 \mathrm{ef}$ & $7.68 \mathrm{~d}$ & $3.87 \mathrm{~b}$ & $1.92 \mathrm{c}-\mathrm{g}$ \\
Koregon PR-380 & $3.87 \mathrm{a}-\mathrm{d}$ & $1.33 \mathrm{bc}$ & $8.85 \mathrm{a}-\mathrm{d}$ & $4.58 \mathrm{ab}$ & $2.09 \mathrm{a}-\mathrm{d}$ \\
PR-power & $3.76 \mathrm{~b}-\mathrm{e}$ & $1.29 \mathrm{~b}-\mathrm{d}$ & $8.58 \mathrm{a}-\mathrm{d}$ & $4.35 \mathrm{~b}$ & $2.03 \mathrm{~b}-\mathrm{e}$ \\
Tantan & $3.80 \mathrm{~b}-\mathrm{e}$ & $1.13 \mathrm{ef}$ & $8.14 \mathrm{~cd}$ & $4.03 \mathrm{~b}$ & $2.22 \mathrm{ab}$ \\
PR901 & $3.98 \mathrm{ab}$ & $1.07 \mathrm{ef}$ & $8.77 \mathrm{a}-\mathrm{d}$ & $5.61 \mathrm{ab}$ & $2.32 \mathrm{a}$ \\
PR919 & $3.59 \mathrm{c}-\mathrm{f}$ & $1.05 \mathrm{ef}$ & $8.31 \mathrm{~b}-\mathrm{d}$ & $3.61 \mathrm{~b}$ & $1.75 \mathrm{~g}$ \\
PR920 & $3.85 \mathrm{a}-\mathrm{d}$ & $1.17 \mathrm{~d}-\mathrm{f}$ & $8.70 \mathrm{a}-\mathrm{d}$ & $4.32 \mathrm{~b}$ & $2.16 \mathrm{a}-\mathrm{c}$ \\
PR921 & $3.34 \mathrm{f}$ & $1.15 \mathrm{~d}-\mathrm{f}$ & $7.76 \mathrm{~cd}$ & $5.74 \mathrm{ab}$ & $1.92 \mathrm{~b}-\mathrm{d}$ \\
PR922 & $3.83 \mathrm{~b}-\mathrm{e}$ & $1.18 \mathrm{c}-\mathrm{e}$ & $9.03 \mathrm{a}-\mathrm{d}$ & $6.82 \mathrm{a}$ & $2.06 \mathrm{~b}-\mathrm{e}$ \\
PR927 & $3.73 \mathrm{~b}-\mathrm{e}$ & $1.01 \mathrm{f}$ & $9.06 \mathrm{a}-\mathrm{d}$ & $4.71 \mathrm{ab}$ & $1.77 \mathrm{f}-\mathrm{g}$ \\
PR928 & $3.53 \mathrm{~d}-\mathrm{f}$ & $1.04 \mathrm{ef}$ & $8.77 \mathrm{a}-\mathrm{d}$ & $5.43 \mathrm{ab}$ & $1.83 \mathrm{e}-\mathrm{g}$ \\
PR929 & $4.20 \mathrm{a}$ & $1.18 \mathrm{c}-\mathrm{e}$ & $9.91 \mathrm{a}$ & $5.25 \mathrm{ab}$ & $1.97 \mathrm{~b}-\mathrm{g}$ \\
PR930 & $3.73 \mathrm{~b}-\mathrm{e}$ & $1.37 \mathrm{~b}$ & $9.74 \mathrm{ab}$ & $4.63 \mathrm{ab}$ & $2.33 \mathrm{a}$ \\
\hline
\end{tabular}

${ }^{z}$ Means separation within columns by Duncan's multiple range test $(P \leq 0.05)$.

fruits grafted onto 'PR 919', and lowest in those grafted onto 'Tantan'.

\section{Survival of Grafted Seedlings after Inoculation of P. capsici}

Survival rate of pepper seedlings after inoculation with
P. capsici as influenced by different rootstocks is presented in Fig. 1. 'Nokkwang' was highly susceptible and all of the inoculated non-grafted and auto-grafted seedlings died. The seedlings showed typical symptoms of Phytophthora blight such as browninsh lesions on stem, plant wilt, leaf defoliation, and damping-off. Among seedlings grafted onto 
Table 5. Cumulative yield of grafted pepper ('Nokkwang') as influenced by grafting and rootstocks.

\begin{tabular}{|c|c|c|c|}
\hline Rootstock & Marketable yield (g/plant) & Unmarketable yield ( $\mathrm{g} / \mathrm{plant}$ ) & Gross yield (g/plant) \\
\hline Non-graft & $1,960 a^{z}$ & $454 a$ & $2,414 a b$ \\
\hline Auto-graft & $1,683 a b$ & $268 b$ & $1,951 a b$ \\
\hline Kataguruma & 1,529ab & $337 a b$ & 1,866ab \\
\hline Konesianhot & $1,783 a b$ & $396 a b$ & $2,636 a$ \\
\hline Koregon PR-380 & 1,533ab & $331 a b$ & $1,864 a b$ \\
\hline PR-power & $1,784 a b$ & $306 a b$ & 2,090ab \\
\hline Tantan & $1,668 a b$ & $376 a b$ & $2,044 a b$ \\
\hline PR901 & $1,945 a$ & $374 a b$ & $2,320 a b$ \\
\hline PR919 & $1,784 a b$ & $335 a b$ & $2,119 a b$ \\
\hline PR920 & $1,525 \mathrm{ab}$ & $316 a b$ & $1,841 \mathrm{ab}$ \\
\hline PR921 & $1,557 a b$ & $290 a b$ & $1,847 a b$ \\
\hline PR922 & $1,611 \mathrm{ab}$ & 339ab & 1,951ab \\
\hline PR927 & $1,918 a b$ & $376 a b$ & $2,294 a b$ \\
\hline PR928 & $1,352 b$ & $266 b$ & $1,618 b$ \\
\hline PR929 & $1,592 a b$ & $306 a b$ & $1,898 a b$ \\
\hline PR930 & $1,625 a b$ & $356 a b$ & $1,981 a b$ \\
\hline
\end{tabular}

${ }^{z}$ Means separation within columns by Duncan's multiple range test $(P \leq 0.05)$.

Table 6. Fruit quality of grafted pepper ('Nokkwang') as influenced by grafting and rootstocks.

\begin{tabular}{|c|c|c|c|c|c|c|}
\hline \multirow{2}{*}{ Rootstock } & \multirow{2}{*}{$\begin{array}{l}\text { Fruit length } \\
\qquad(\mathrm{cm})\end{array}$} & \multirow{2}{*}{$\begin{array}{l}\text { Fruit width } \\
\quad(\mathrm{mm})\end{array}$} & \multirow{2}{*}{$\begin{array}{l}\text { Flesh thickness } \\
\qquad(\mathrm{mm})\end{array}$} & \multirow{2}{*}{$\begin{array}{c}\text { Fresh weight } \\
\text { (g) }\end{array}$} & \multicolumn{2}{|c|}{ Textural property } \\
\hline & & & & & Strength $\left(\mathrm{kN} \cdot \mathrm{m}^{-2}\right)$ & Hardness $\left(\mathrm{kN} \cdot \mathrm{m}^{-2}\right)$ \\
\hline Non-graft & $12.0 d^{2}$ & $14.6 a$ & $1.58 a b$ & $10.9 c-e$ & $569 a-c$ & $5,551 b-d$ \\
\hline Auto-graft & $12.4 a-d$ & $14.6 \mathrm{a}$ & $1.54 a b$ & 11.3b-e & $537 \mathrm{bc}$ & $5,363 \mathrm{~cd}$ \\
\hline Kataguruma & $12.4 \mathrm{~b}-\mathrm{d}$ & $14.5 \mathrm{a}$ & $1.57 a b$ & $11.7 a-c$ & $545 a b$ & $5,446 b-d$ \\
\hline Konesianhot & $12.7 a b$ & $14.7 \mathrm{a}$ & $1.66 a$ & $12.1 \mathrm{a}$ & 568a-c & $5,331 \mathrm{~cd}$ \\
\hline Koregon PR-380 & $12.5 a-d$ & $14.4 a$ & $1.50 \mathrm{ab}$ & 11.3b-e & 569a-c & $5,275 \mathrm{~cd}$ \\
\hline PR-power & $12.4 a-d$ & $14.8 \mathrm{a}$ & $1.59 a$ & $11.1 \mathrm{~b}-\mathrm{e}$ & $550 \mathrm{bc}$ & $5,577 \mathrm{~b}-\mathrm{d}$ \\
\hline Tantan & $12.3 b-d$ & $14.6 a$ & $1.62 a$ & $11.5 a-d$ & $546 \mathrm{bc}$ & $5,135 d$ \\
\hline PR901 & $12.9 a$ & $14.8 \mathrm{a}$ & $1.66 \mathrm{a}$ & $11.8 a b$ & $547 \mathrm{bc}$ & $5,337 \mathrm{~cd}$ \\
\hline PR919 & $12.5 a-d$ & $14.6 a$ & $1.52 \mathrm{ab}$ & $11.5 a-d$ & $623 a$ & $6,397 a$ \\
\hline PR920 & $12.5 a-d$ & $14.4 a$ & $1.54 a b$ & $10.9 c-e$ & $596 a b$ & $6,249 a b$ \\
\hline PR921 & $12.1 \mathrm{~cd}$ & $14.5 \mathrm{a}$ & $1.54 a b$ & 10.8de & $584 a-c$ & $5,502 \mathrm{~b}-\mathrm{d}$ \\
\hline PR922 & $12.6 a-c$ & $15.0 \mathrm{a}$ & $1.50 \mathrm{ab}$ & $11.7 a-c$ & $564 a-c$ & $5,521 b-d$ \\
\hline PR927 & $12.6 a-c$ & $14.8 \mathrm{a}$ & $1.53 a b$ & $11.4 a-d$ & 567a-c & $5,934 a-d$ \\
\hline PR928 & $12.3 \mathrm{~b}-\mathrm{d}$ & $14.6 a$ & $1.42 b$ & $10.5 \mathrm{e}$ & $529 c$ & $5,216 \mathrm{~cd}$ \\
\hline PR929 & $12.1 \mathrm{~cd}$ & $15.0 \mathrm{a}$ & $1.54 a b$ & 10.8de & $562 a-c$ & $6,011 a-c$ \\
\hline PR930 & $12.3 \mathrm{~b}-\mathrm{d}$ & $14.8 \mathrm{a}$ & $1.49 a b$ & $11.3 \mathrm{~b}-\mathrm{e}$ & 577a-c & 5,798a-d \\
\hline
\end{tabular}

${ }^{z}$ Means separation within columns by Duncan's multiple range test $(P \leq 0.05)$.

commercial rootstocks, the seedlings grafted onto 'Tantan' and 'Kataguruma' showed high resistance. The survival rates of the seedlings were $100 \%$ and $89 \%$, respectively. Among seedlings grafted onto breeding lines, these seedlings grafted onto 'PR 920', 'PR 921', and 'PR 922' showed high resistance. The survival rates of these seedlings were $100 \%$, $100 \%$, and $89 \%$, respectively.
The Growth and Incidence of Phytophthora Blight and Bacterial Wilt of the Grafted Peppers Influenced by Different Rootstocks

Graft-take and Growth of Grafted Seedlings

Different scions or rootstocks didn't affect the graft-take (Fig. 2). The graft-take ranged from $79 \%$ to $96 \%$ according 


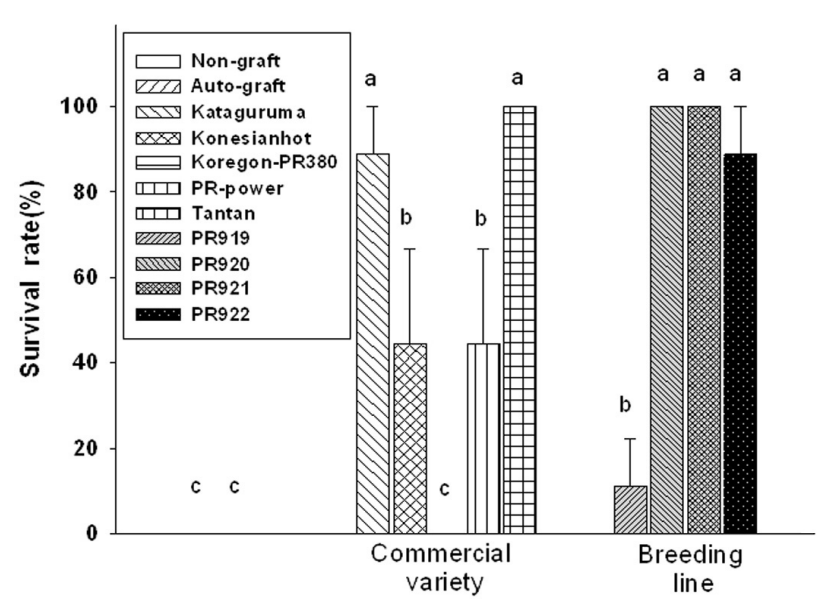

Fig. 1. Survival rate of peppers after inoculation with Phytophthora capsici as influenced by grafting and rootstocks. Vertical bars represent standard error. Different letters are significantly different at $P \leq 0.05$ (Duncan's multiple range test).

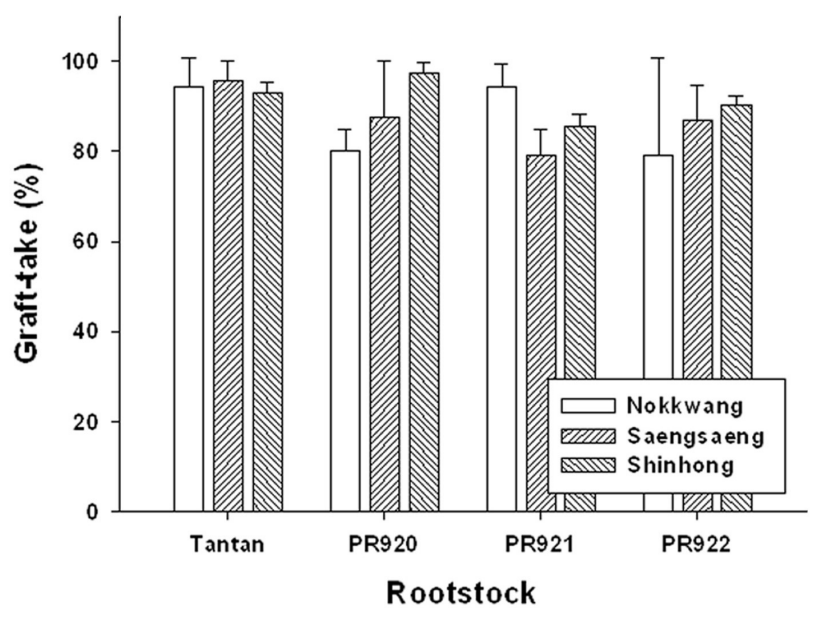

Fig. 2. Graft-take of peppers grafted onto different rootstocks at 10 days after grafting. Vertical bars represent standard error.

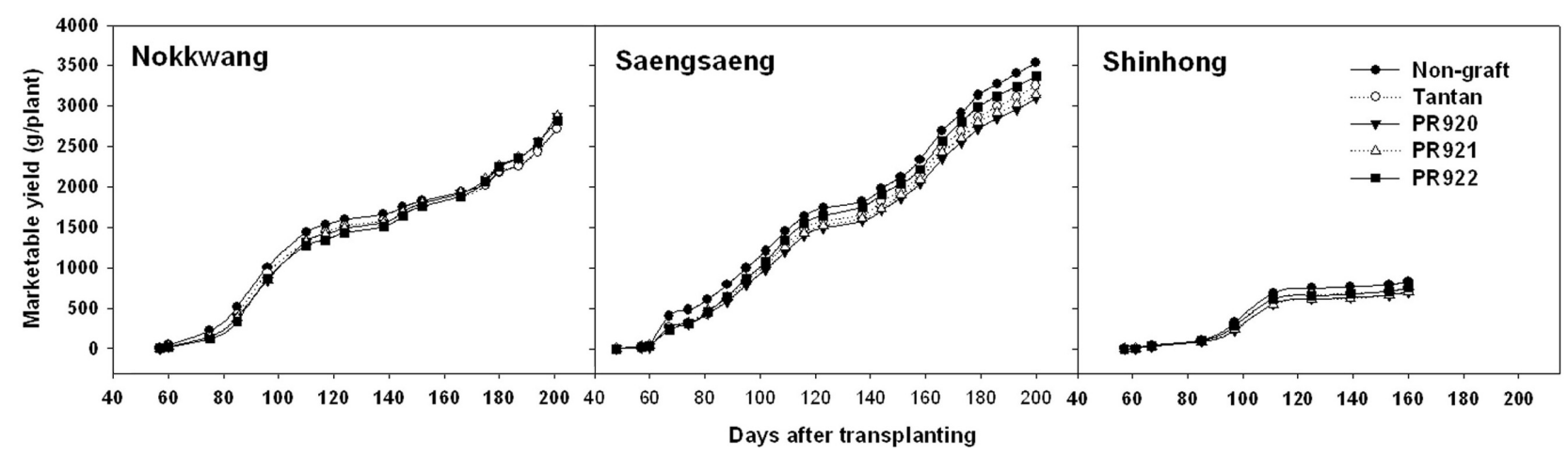

Fig. 3. Cumulative yield of marketable fruits of grafted pepper ('Nokkwang', 'Saensaeng', and 'Shinhong') as influenced by grafting and rootstocks.

to the combinations of scions and rootstocks. The graft-take of seedlings grafted onto 'Tantan' averaged 94\%. Those of seedlings grafted onto 'PR 920', 'PR 921', and 'PR 922' averaged $88 \%, 86 \%$, and $85 \%$, respectively.

The growth of pepper seedlings were influenced by grafting (Table 7). Shoot length, stem diameter, and leaf area of the non-grafted seedlings were greater than those of grafted seedlings. The growth varied among combinations of scions and rootstocks. In 'Nokkwang', the dry weight was highest in the non-grafted seedlings followed by seedlings grafted onto 'Tantan' and 'PR 922'. In 'Saengsaeng Matkkwari', the dry weight was highest in the seedlings grafted onto 'PR 921'. In 'Shinhong', the dry weight was highest in the non-grafted seedlings followed by seedlings grafted onto 'Tantan' and 'PR 921'.

\section{Yield and Fruit Quality of Grafted Peppers}

Cumulative yields of marketable fruits are presented in Fig. 3. The yields were different depending on scion var- ieties, but significant differences among treatments were not found. Moreover, no significant differences in fruit quality were found (Table 8).

\section{Incidence of Grafted Seedlings after Inoculation of} $P$. capsici and $R$. solanacearum

Incidence of pepper seedlings after inoculation with $P$. capsici and $R$. solanacearum as influenced by different rootstocks are presented in Fig. 4. The inoculated scion varieties were susceptible to $P$. capsici, and non-grafted seedlings exhibited infection symptom in five days after and then all died. On the other hand, the incidence of Phytophthora blight on grafted seedlings were markedly lower than those of non-grafted seedlings, and showed high resistance to $P$. capsici. The incidence of seedlings grafted onto breeding lines ('PR 920', 'PR 921', and 'PR 922') was delayed and lower than those grafted onto commercial rootstock 'Tantan'.

Incidence of pepper seedlings inoculated with $R$. solanacearum was different depending on scion varieties. In 
Table 7. Growth of grafted pepper seedlings ('Nokkwang', 'Saengsaeng', and 'Shinhong') as influenced by grafting and rootstocks.

\begin{tabular}{|c|c|c|c|c|c|c|c|}
\hline \multicolumn{2}{|l|}{ Treatment } & \multirow{2}{*}{$\begin{array}{l}\text { Shoot length } \\
(\mathrm{cm})\end{array}$} & \multirow{2}{*}{$\begin{array}{l}\text { Number of } \\
\text { leaves }\end{array}$} & \multirow{2}{*}{$\begin{array}{l}\text { Stem diameter } \\
\text { of } \operatorname{scion}^{z}(\mathrm{~mm})\end{array}$} & \multirow{2}{*}{$\begin{array}{l}\text { Leaf area } \\
\left(\mathrm{cm}^{2}\right)\end{array}$} & \multicolumn{2}{|c|}{ Dry weight (mg) } \\
\hline Scion & Rootstock & & & & & Root & Shoot \\
\hline \multirow[t]{5}{*}{ Nokkwang } & Non-graft & $36 a^{y}$ & $16.4 a$ & $4.22 a$ & $192 a$ & $148 a$ & $966 a$ \\
\hline & Tantan & $32 b$ & $13.0 \mathrm{~b}$ & $3.20 b$ & $188 b$ & $86 b$ & $798 b$ \\
\hline & PR920 & $24 c$ & $12.8 b$ & $2.71 \mathrm{c}$ & $141 c$ & $50 c$ & $534 c$ \\
\hline & PR921 & $25 c$ & $12.6 \mathrm{~b}$ & $2.74 c$ & $149 c$ & $50 c$ & $596 c$ \\
\hline & PR922 & $25 c$ & $12.8 \mathrm{~b}$ & $2.80 c$ & 157c & $66 c$ & $620 c$ \\
\hline \multirow[t]{5}{*}{ Saengsaeng } & Non-graft & $41 a$ & $22.6 a$ & $3.06 a$ & $218 a$ & $130 a$ & $886 a$ \\
\hline & Tantan & $29 b$ & $17.4 \mathrm{~b}$ & $2.76 \mathrm{~b}$ & $187 \mathrm{bc}$ & $84 b$ & $758 a b$ \\
\hline & PR920 & $29 c$ & $17.2 \mathrm{~b}$ & $2.98 b$ & $162 c$ & $72 b$ & $622 b$ \\
\hline & PR921 & $30 c$ & $21.2 \mathrm{ab}$ & $2.90 b$ & $190 a-c$ & $138 a$ & $928 a$ \\
\hline & PR922 & $32 c$ & $23.2 a$ & $2.99 \mathrm{~b}$ & $207 a b$ & $66 \mathrm{~b}$ & $620 b$ \\
\hline \multirow[t]{5}{*}{ Sinhong } & Non-graft & $42 a$ & $21.8 a$ & $3.44 a$ & $210 a$ & $134 a$ & $1,050 \mathrm{a}$ \\
\hline & Tantan & $32 b$ & $16.0 \mathrm{~b}$ & $3.01 b$ & $178 a b$ & $78 \mathrm{~cd}$ & $688 b$ \\
\hline & PR920 & $30 \mathrm{~b}$ & $17.4 \mathrm{~b}$ & $3.17 a b$ & $170 b$ & $102 b c$ & $774 b$ \\
\hline & PR921 & $25 c$ & $18.8 a b$ & $3.46 a$ & $174 b$ & $108 b$ & $804 b$ \\
\hline & PR922 & $30 \mathrm{~b}$ & $16.4 b$ & $3.02 b$ & $184 a b$ & $72 d$ & $656 b$ \\
\hline Scion (A) & & $* * \star x$ & $\star * *$ & $* * *$ & $* * *$ & $* \star *$ & * \\
\hline Rootstock (B) & & $* * *$ & $*$ & ns & $* *$ & $* \star *$ & $* * *$ \\
\hline$A \times B$ & & $* * *$ & $* *$ & $* *$ & ns & $* * *$ & $* * *$ \\
\hline
\end{tabular}

${ }^{\mathrm{z}}$ Stem diameter was measured at $1 \mathrm{~cm}$ above the graft union.

${ }^{\mathrm{y}}$ Means separation within columns for each scion variety by Duncan's multiple range test $(P \leq 0.05)$.

"ns indicates nonsignificant; *significant at $P \leq 0.05$; ${ }^{* *}$ significant at $P \leq 0.01$; ${ }^{* * *}$ significant at $P \leq 0.001$.

Table 8. Fruit quality of grafted pepper ('Nokkwang', 'Saengsaeng', and 'Shinhong') as influenced by grafting and rootstocks.

\begin{tabular}{|c|c|c|c|c|c|}
\hline \multicolumn{2}{|l|}{ Treatment } & \multirow{2}{*}{$\begin{array}{l}\text { Fruit length }{ }^{z} \\
(\mathrm{~cm})\end{array}$} & \multirow{2}{*}{$\begin{array}{l}\text { Fruit width } \\
(\mathrm{mm})\end{array}$} & \multirow{2}{*}{$\begin{array}{l}\text { Flesh thickness } \\
(\mathrm{mm})\end{array}$} & \multirow{2}{*}{$\begin{array}{c}\text { Fruit weight } \\
\text { (g) }\end{array}$} \\
\hline Scion & Rootstock & & & & \\
\hline \multirow[t]{5}{*}{ Nokkwang } & Non-graft & 12.04 & 14.98 & 2.36 & $10.39 b^{y}$ \\
\hline & Tantan & 11.95 & 14.69 & 2.29 & $10.26 b$ \\
\hline & PR920 & 12.42 & 15.18 & 2.20 & $11.47 a$ \\
\hline & PR921 & 11.97 & 14.45 & 2.24 & $9.99 b$ \\
\hline & PR922 & 12.16 & 14.74 & 2.29 & $10.57 b$ \\
\hline \multirow[t]{5}{*}{ Saengsaeng } & Non-graft & 9.69 & 10.53 & 1.49 & 4.33 \\
\hline & Tantan & 9.73 & 10.86 & 1.38 & 4.52 \\
\hline & PR920 & 9.77 & 10.59 & 1.52 & 4.39 \\
\hline & PR921 & 9.89 & 11.12 & 1.46 & 4.70 \\
\hline & PR922 & 9.36 & 10.92 & 1.48 & 4.15 \\
\hline \multirow[t]{5}{*}{ Sinhong } & Non-graft & 8.53 & $10.55 a b$ & 1.76 & 4.60 \\
\hline & Tantan & 8.73 & $10.60 \mathrm{a}$ & 1.62 & 4.53 \\
\hline & PR920 & 8.13 & 10.17ab & 1.67 & 4.12 \\
\hline & PR921 & 7.75 & $10.34 a b$ & 1.67 & 4.22 \\
\hline & PR922 & 8.04 & $9.90 \mathrm{~b}$ & 1.70 & 4.11 \\
\hline Scion $(A)$ & & $* * * x$ & $* * *$ & $* * *$ & $* * *$ \\
\hline Rootstock (B) & & ns & ns & ns & ns \\
\hline$A \times B$ & & ns & * & ns & $* * *$ \\
\hline
\end{tabular}

${ }^{\mathrm{z}}$ Fruits $(\mathrm{n}=30)$ were selected at 76 days after transplanting.

${ }^{\mathrm{y}}$ Means separation within columns for each scion variety by Duncan's multiple range test $(P \leq 0.05)$.

${ }^{\times}$ns indicates nonsignificant; *significant at $P \leq 0.05$; ${ }^{* *}$ significant at $P \leq 0.01$; ${ }^{* *}$ significant at $P \leq 0.001$.

scion 'Nokkwang', the incidence of seedlings grafted onto breeding lines ('PR 920', 'PR 921', and 'PR 922') was delayed and lower than non-grafted seedlings and those grafted onto commercial rootstock 'Tantan'. In scion 'Saengsaeng', the incidence was highest in seedlings grafted onto commercial rootstock 'Tantan'. The survival rates of the non-grafted 'Nokkwang', 'Saengsaeng Matkkwari', and 'Shinhong' were $67 \%, 83 \%$, and $100 \%$, respectively. 'Shinhong' showed high resistance to $P$. capsici. In 'Nokkwang', the survival rates increased by grafting and those of seedlings 

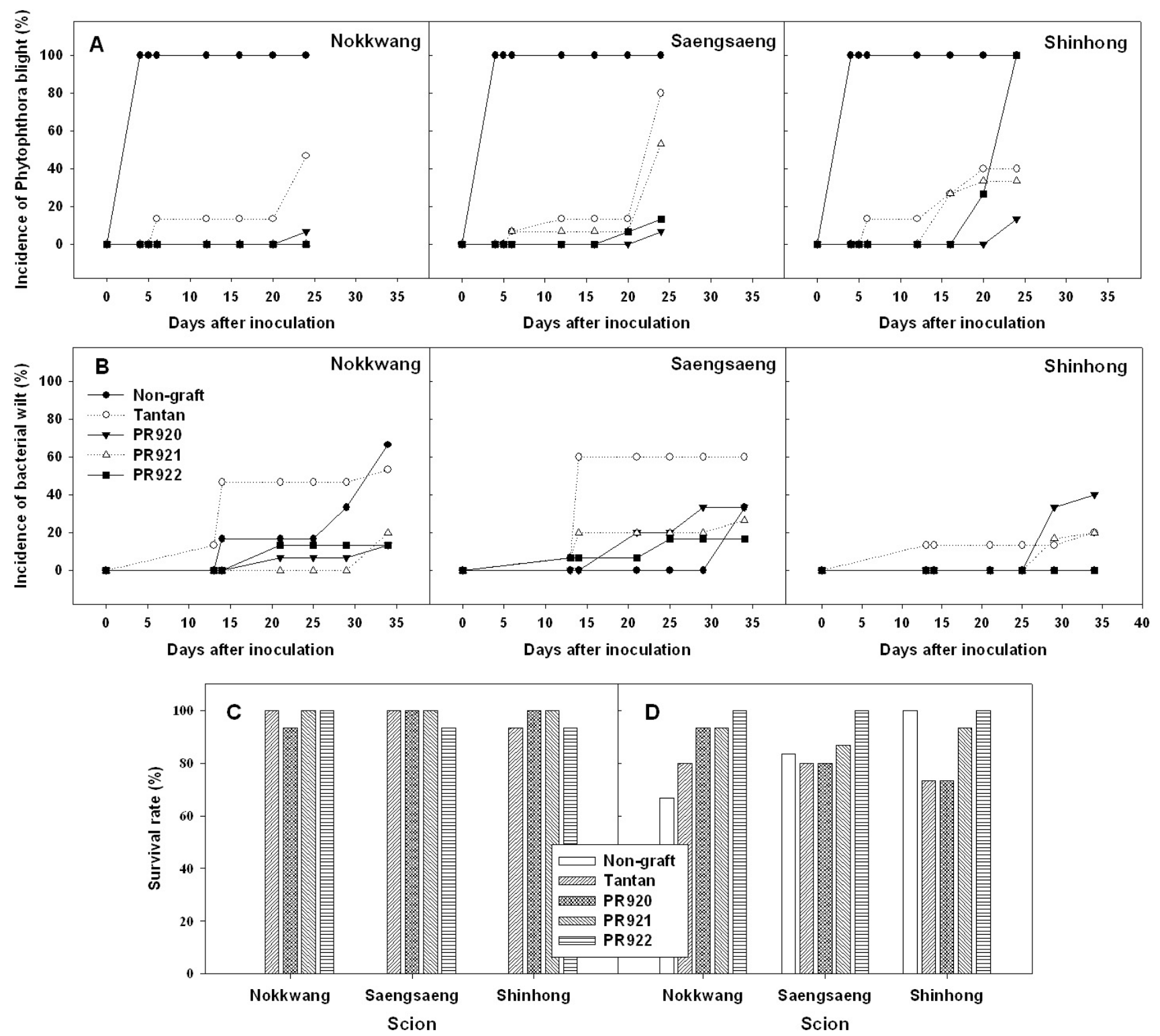

Fig. 4. Incidence of Phytophthora blight $(A)$ and bacterial wilt $(B)$ and survival rate of pepper seedlings after inoculation with (C) Phytophthora capsici and (D) Ralstonia solanacearum as influenced by grafting and rootstocks.

grafted onto breeding lines were greater than that of commercial variety 'Tantan'. In 'Saengsaeng Matkkwari', the survival rate was highest in the seedlings grafted onto 'PR 922' followed by 'PR 920'. In 'Shinhong', the survival rate was highest in the non-grafted seedlings followed by seedlings grafted onto 'PR 922' and 'PR 921'. The average survival rates of pepper seedlings grafted onto 'Tantan', 'PR 920', 'PR 921', and 'PR 922' were 78\%, 82\%, 91\% and $100 \%$, respectively, and 'PR 922' showed the highest resistance.

\section{Discussion}

Vegetable grafting is globally conducted because it can increase disease resistance, abiotic stress tolerance, yield and quality of a number of vegetable crops (Davis et al., 2008b; King et al., 2008, 2010; Lee and Oda, 2003; Lee et al., 2010; Rivero et al., 2003). This can be achieved by using rootstocks that have resistance to soilborne diseases or pests, tolerance to abiotic stress, selective absorption of available nutrients, high vigor and good compatibility with the scion (Davis et al., 2008b; Gisbert et al., 2011; Lee and Oda, 2003; Rivero et al., 2003). In this study, C. annuиm commercial rootstocks and breeding lines for rootstock were tested for resistance to Phytophthora blight and bacterial wilt as well as their graft compatibility to commercial pepper cultivars, and have confirmed that the new pepper rootstock is resistant to both Phytophthora blight and bacterial wilt.

Seed germination and grafting success are very important 
in using grafted crops. Some rootstocks of wild species such as wild Solanum are known to emerge slowly and have poor germination (Gisbert et al., 2011). In this study, commercial varieties exhibited high percent germination, but some breeding lines showed lower percent germination. Grafting success does not only depend on environmental factors and skill of the grafter but also on graft compatibility between rootstock and scion (Davis et al., 2008b; Gisbert et al., 2011). Even though the scion and rootstock are same species (C. аппиит L.) in grafted pepper production, grafting success is affected by the combination of scion and rootstock. Different graft-takes were achieved between different scionrootstock combinations. The graft-takes of selected breeding lines ('PR 920', 'PR 921', and 'PR 922') averaged over $80 \%$.

Grafting also affects the growth and mineral contents of grafted plants (Edelstein et al, 2010; Ruiz et al., 1997; Savvas et al., 2010). In this study, growth parameters such as shoot length, number of leaves, dry weight, and mineral contents were different according to the combinations of scions and rootstocks. Since both the root structure and the uptake efficiency of the root cells are determined by the rootstock, plants grafted onto different rootstocks may exhibit dissimilar abilities to take up and translocate nutrients (Savvas et al., 2010).

It is reported that grafting can increase yield since grafted plants are resistant to soilborn disease, have strong root systems, and increased photosynthesis (Davis et al., 2008b). It has been also reported that $\mathrm{pH}$, flavor, sugar, color, carotenoid content, and texture can be affected by grafting and the type of rootstock used and the rootstock/scion combination must be carefully chosen for optimal fruit quality (Davis et al., 2008a; Gisbert et al., 2011). In this study, we found no differences for yield and apparent fruit quality among non-grafted peppers or peppers onto 'Tantan' and selected breeding lines ('PR 920', 'PR 921', and 'PR 922'). However, there were some differences for apparent fruit quality among commercial and breeding rootstocks. For example, rootstocks affected fruit length, possibly due to changes in the concentration of growth regulators induced by the rootstock (Gisbert et al., 2011).

Phytophtora blight caused by $P$. capsici and bacterial wilt caused by $R$. solanacearum are the most economically important and destructive diseases in pepper production (Kim et al., 2010; Tran and Kim, 2010). When grafted pepper seedlings are grafted onto commercial rootstocks and selected breeding lines were inoculated with $P$. capsici, the grafted seedlings showed variation in resistance according to rootstock genotypes (Fig. 1). Some commercial rootstocks were found to have low level of resistance or susceptiblility to the disease, although their names were initialed with 'PR' meaning Phytophthora resistance or they were known as resistant cultivar (Kim et al., 2010). Breeding lines 'PR 920', 'PR 921', and 'PR 922' were found to be highly resistant to Phytophthora blight. These lines also showed higher resistance to bacterial wilt than commercial rootstock 'Tantan' (Fig. 4).

Among non-grafted seedlings (scion varieties), 'Shinhong' showed very high resistant to bacterial wilt followed by 'Saengsaeng Matkkwari'. This result agreed with the report about resistance to bacterial wilt of commercial peppers (NIHHS, 2009). The NIHHS reported that 'Shinhong' has the highest resistance followed by 'Saengsaeng Matkkwari', while 'Nokkwang' was susceptible to bacterial wilt. In 'Nokkwang', the resistance to bacterial wilt was increased by grafting using commercial rootstock and breeding lines. However, in 'Shinhong' and 'Saengsaeng Matkkwari', the resistance of grafted seedlings was influenced by scion/ rootstock combinations and the specific combination negatively impacted the resistance. Thus, the rootstock/ scion combination should be carefully chosen for obtaining resistance, optimal yield and fruit quality.

Peppers grafted onto breeding lines of 'PR 920', 'PR 921', and 'PR 922' had shown high resistance to both Phytophthora blight and bacterial wilt without decrease in yield and fruit quality. Accordingly, they were considered to be used as rootstocks resistant to Phytophthora and bacterial wilt for pepper production.

Greater resistance to both Phytophthora blight and bacterial wilt can be obtained when peppers were grafted onto resistant breeding lines such as 'PR 920', 'PR 921', and 'PR 922' without the reduction in yield and apparent fruit quality, and these resistance breeding lines could effectively be used as a source of rootstock.

In conclusion, grafting using rootstocks resistant to both Phytophthora blight and bacterial wilt seems to be an effective tool for disease resistance. Pepper scions grafted onto breeding lines ('PR 920', 'PR 921', and 'PR 922') resistant to both Phytophthora blight and bacterial wilt showed greater survival rate when they were inoculated with $P$. capsici and $R$. solanacearum. The grafted peppers didn't exhibit any detrimental effect on yield and apparent fruit quality. Accordingly, selected breeding lines are recommended as candidates of pepper rootstock resistant to both Phytophthora blight and bacterial wilt.

\section{Literature Cited}

Chung, H. and Y. Choi. 2002. Enhancement of salt tolerance of pepper plants (Capsicum annuum) by grafting. J. Kor. Soc. Hort. Sci. 43:556-564.

Davis, A.R., P. Perkins-Veazie, R. Hassell, A. Levi, S.R. King, and X. Zhang. 2008a. Grafting effects on vegetable quality. Hortscience 43:1670-1672.

Davis, A.R., P. Perkins-Veazie, Y. Sakata, S. L'opez-Galarza, J.V. 
Maroto, S.G. Lee, Y.C. Huh, Z. Sun, A. Miguel, S.R. King, R. Cohen, and J.M. Lee. 2008b. Cucurbit grafting. Critical Rev. Plant Sci. 27:50-74.

Edelstein, M, Z. Plaut, and M. Ben-Hur. 2011. Sodium and chloride exclusion and retention by non-grafted and grafted melon and Cucurbita plants. J. Experimental Botany 62:177-184.

Gisbert, C., J. Prohensa, M.D. Raigonb, J. R. Stommelc, and F. Nueza. 2011. Eggplant relatives as sources of variation for developing new rootstocks: Effects of grafting on eggplant yield and fruit apparent quality and composition. Scientia Hort. 128:14-22.

Jang, Y.A., Y.Y. Cho, H.C. Rhee, and Y.C. Um. 2008. Effects of rootstock and night temperature on the growth and yield of grafted pepper (Capsicum annuum L.). Hort. Environ. Biotechnol. 49:63-71.

Kim, B.S., T.R. Kwon, J.E. Hwang, J.M. Lee, D.G. Park, J.H. Ahn, and H.Y. Kim. 2010. Resistance to Phytophthora blight of commercial pepper cultivar in Korea. Res. Plant Dis. 16:141-147.

Kim, C.H. and Y.K. Kim. 2002. Present status of soilborne disease incidence and scheme for its integrated management in Korea. Res. Plant Dis. 8:146-161.

Kim, J.S., W.I. Kim, H.J. Jee, J.G. Gwang, C.K. Kim, and C.K. Shim. 2010. Evaluation of resistance in hot pepper germplasm to Phytophthora blight on biological assay. Kor. J. Hort. Sci. Technol. 28:802-809.

King, S.R., A.R. Davis, W. Liu, and A. Levi. 2008. Grafting for disease resistance. Hortscience 43:1673-1676.

King, S.R., A.R. Davis, X. Zhang, and K. Crosby. 2010. Genetics, breeding and selection of rootstocks for Solanaceae and Cucurbitaceae. Scientia Hort. 127:106-111.

Lee, J. and M. Oda. 2003. Grafting of herbaceous vegetable and ornamental crops. Hort. Rev. 28:61-124.

Lee, J.M., C. Kubota, S.J. Tsao, Z. Bie, P. Hoyos Echevarria, L. Morra, and M. Oda. 2010. Current status of vegetable grafting: Diffusion, grafting techniques, automation. Scientia Hort. 127: 93-105.

Louws, F.J., C.L. Rivard, and C. Kubota. 2010. Grafting fruiting vegetables to manage soilborne pathogens, foliar pathogens, arthropods and weeds. Scientia Hort. 127:127-146.

Ministry for Food, Agriculture, Forestry, and Fisheries (MIFAFF). 2010. Statistics about vegetable production for 2009. MIFAFF, Seoul, Korea p. 9.

Myung, I.S., S.K. Hong, Y.K. Lee, H.W. Choi, H.S. Shim, J.W. Park, K.S. Park, S.Y. Lee, S.D. Lee, S.H. Lee, H.S. Choi, Y.G. Kim,
D.B. Shin, D.S. Ra, W.H. Yeh, S.S. Han, and W.D. Cho. 2006. Review of disease incidences of major crops of the South Korea in 2005. Res. Plant Dis. 12:153-157.

National Institute of Horticultural \& Herbal Science (NIHHS). 2009. Horticultural and herbal research annual report for 2008 (I). NIHHS, Suwon, Korea p. 265-351.

Oka, Y., R. Offenbach, and S. Pivonia. 2004. Pepper rootstock graft compatibility and response to Meloidogyne javanica and $M$. incognita. J. Nematology 36:137-141.

Rivard, C.L. and F.J. Louws. 2008. Grafting to manage soilborne diseases in heirloom tomato production. Hortscience 43:2104-2111.

Rivero, R.M., J.M. Ruiz, and L. Romero. 2003. Role of grafting in horticultural plants under stress conditions. J. Food Agr. Environ. 1:70-74.

Ruiz, J.M., A. Belakbir, I. López-Cantarero, and L. Romero. 1997. Leaf-macronutrient content and yield in grafted melon plants. A model to evaluate the influence of rootstock genotype. Scientia Hort. 71:227-234.

Rural Development Administration (RDA). 2008a. Pepper cultivation (The textbook for farming no. 115). RDA, Suwon, Korea.

Rural Development Administration (RDA). 2008b. Vegetable transplant production (The textbook for farming no. 86). RDA, Suwon, Korea.

Savvas, D., G. Colla, Y. Rouphael, and D. Schwarz. 2010. Amelioration of heavy metal and nutrient stress in fruit vegetables by grafting. Scientia Hort. 127:156-161.

Semi, Y., T. Sugita, S. Imuta, T. Kurogi, T. Kinoshita, and R. Nagata. 2010. Evaluation of resistance to bacterial wilt and breeding of a new resistant rootstock cultivar in Capsicum annuum L. Hort. Res. 9:287-292.

Tran, N.H. and B.S. Kim. 2010. Inheritance of resistance to bacterial wilt (Ralstonia solanacearum) in pepper (Casicum annuum L.). Hort. Environ. Biotechnol. 51:431-439.

Yang, E.Y., M.C. Cho, S.Y. Chae, Y.A. Jang, H.J. Lee, H.S. Choi, H.B. Jeong, and S.R. Cheong. 2010. Breeding of multiple disease resistant rootstock variety to Phytophthora blight and bacterial wilt in pepper (Capsicum annuum), p. 529-534. In: J. Prohens and A. RodriguezBurruezo (eds.). Advances in genetics and breeding of Capsicum and eggplant. EUCARPIA, Valencia, Spain.

Yeon, C., S.M. Lee, S.B. Kim, S.Y. Min, and H.T. Kim. 2008. The change of resistance of Phytophthora infestans to metalaxyl and the relationship with the pathogenicity on pepper plants. Korean J. Pesticide Sci. 12:270-276. 